\title{
Den fælles horisont
}

\author{
Didaktik og dannelse i religionsundervisning
}

\begin{abstract}
Av Lakshmi Sigurdsson og Keld Skovmand
Artiklen kaster nyt lys over religionsdidaktikken ved at anskue fagvidenskaben, den almene didaktik og den almene dannelsesteori som ligevardige basisfag for religionsundervisning. Artiklen forbinder modeller for dannelsesteoretisk didaktik og udvikling af religiøs myndighed (Klafki, Nielsen, Skovmand og Andersen \& Sigurdsson). Modellernes brug eksemplificeres ved hjoelp af Lignelsen om arbejderne i vingården. Den didaktiske og dannelsesteoretiske bearbejdning af teksten viser, hvordan tilgange til tekster transformeres, når de gøres til genstand for undervisning og ud fra en podagogisk normativitet og en almen didaktisk begrundelsessystematik. Artiklen konkluderer, at religionsundervisningen skal reproesentere viden $i$ en didaktisk reflekteret og omsat form og samtidig vare pluralistisk, idet den underloegges et alment dannelsesformål om myndighed.
\end{abstract}

Nøkkelord: religionsdidaktik, almen didaktik, almen dannelse, lignelse, religiøs myndighed

LaKshmi Sigurdsson, lektor, cand.mag. \& M.Ed., Københavns Professionshøjskole. Mail:las@kp.dk

Keld Skovmand, lektor, ph.d., HistorieLab. Nationalt videncenter for historie og kulturarvsformidling.UCL Erhvervsakademi og professionshøjskole.Mail: kesk@ucl.dk

\section{DEN FELLES HORISONT}

Et alment grundlag for religionsundervisning

Der gælder det samme for religionsundervisning, som der gælder for al anden undervisning i grundskolen: Undervisningen er alment dannende, og principperne for undervisningen bør derfor være funderet i en almen dannelsesteori. Samtidig må undervisningen og dens tilrettelæggelse anskues alment og derfor være begrundet $i$ en almen didaktik. Den fælles horisont for undervisningen er dermed ikke blot fælles for alle, der underviser i religionsfagligt indhold i grundskolen og uddanner hertil, men også for alle grundskolelærere og undervisere i læreruddannelsen. Den fælles horisont varierer, fordi der i hvert fag lægges et bestemt indhold - og bestemte måder at omgås indholdet på - ind i et definerende spændingsforhold mellem den almene dannelsesteori og den almene didaktik.

Fagene lever ikke separate liv i lukkede videnskabelige systemer, hvorfra der siver viden ned i uddannelsessystemet og ud i skolen og omverdenen. Fagene leverer viden, som transformeres i forskellige kontekster, der er underlagt forskellige typer af formål, dvs. forskellige former for normativitet. Grundskolen

Prismet - IKO-Forlaget 2020

Tilgjengelig på https://journals.uio.no/index.php/prismet. Publisert under CC BY-NC 4.o. Fagfellevurdert 
er underlagt en normativitet, som fremgår af dens formål - i den danske folkeskole er det væsentligst «åndsfrihed, ligeværd og demokrati». Samtidig er «almen dannelsesteori» og «almen didaktik» hverken entydige eller statiske størrelser, når de indgår i en fagdidaktisk sammenhæng, fordi enhver fagdidaktik altid vil kaste et specifikt blik på dem og aldrig vil udlægge dem alment.

Ilæreruddannelsen er der også normativitet på spil. Den lærer, som skal indføre eleverne i den fælles verden med en pluralitet af religioner, livssyn og værdiorienteringer, er nødt til at reflektere over forholdet mellem personlig værdiorientering og de værdier, professionen er forpligtet på (jf. Bakker 2016). Læreruddannelsen er dermed også et dannelsesprojekt for den studerende.

Religionsfagligt indhold er kendetegnet ved at rumme og udtrykke sin egen normativitet. Der sker derfor en fordobling eller opblanding af normativitet, når indholdet flyttes fra en religiøs til en pædagogisk kontekst. En bibeltekst har eksempelvis sin egen normativitet, der udlægges på forskellige måder i forskellige konfessionelle sammenhænge, og som udfordres, når konteksten er pædagogisk, og undervisningen er underlagt et alment dannelsesformål.

Vi har to sammenhængende hovedinteresser:

1 Hvad sker med religionsdidaktisk forskning, når den orienterer sig imod dannelse og didaktik?

2 Hvad sker der med religionsfagligt indhold, når det skal omsættes til undervisning, der har et alment dannende sigte?

Først skitserer vi vores to modeller og tilgange og præsenterer vores forskningsposition. Dernæst viser vi med vingårdslignelsen som eksempel, hvad de to modeller kan bruges til, og hvilke frugter tilgangene kan bære. I et mellemafsnit bygger vi bro mellem tilgangene ved at klargøre og forbinde begreberne «didaktik og dannelsesteori».

\section{Modeller og tilgange}

Vi opererer med to modeller og typer af tilgange, som baserer sig på flere tidligere arbejder, som vi i denne artikel videreudvikler og binder sammen. Den ene tilgang og model er «relationsfeltsdidaktisk». Forestillingen om et «relationsfelt» kommer fra Wolfgang Klafki og dermed den almene didaktik, men er blevet fortolket og udvidet af den danske professor i musikdidaktik, Frede V. Nielsen. Han skelner mellem fire kriterier for indholdsvalg og tre didaktiske paradigmer, der knytter sig til disse kriterier.

Nielsen har ikke selv sat sine kriterier op i en model og har heller ikke forsøgt at omsætte dem systematisk til andre fag end musik. Den ene af denne artikels forfattere har i tilknytning til samtaler med Nielsen i flere omgange og former 
omsat kriterierne til en almen fagdidaktisk model, som også har resulteret i en «fagdidaktisk kodeteori» (Skovmand 2017: 200). Modellen og teorien eksemplificeres ved hjælp af Lignelsen om arbejderne i vingården, som i denne artikel anskues i et alment dannelsesteoretisk og religionspædagogisk perspektiv.

Den anden model er en religionspædagogisk model for religiøs myndighed, som trækker på en dannelsesteoretisk tilgang. Den blev udviklet i sammenhæng med et aktionsforskningsprojekt om religionsdidaktik i praksis (Andersen \& Sigurdsson 2019 a og 2019b). Myndighed som horisont for dannelse tager afsæt i det klassiske tyske dannelsesbegreb («Bildung») med det pædagogiske ideal om autonomi, frihed og ansvarlighed (Andersen \& Sigurdsson 2020).

Modellen for dannelse til religiøs myndighed eksemplificeres didaktisk via vingårdslignelsen med fokus på temaet retfærdighed. Således bliver det både klart, hvad dannelse til religiøs myndighed kan indebære i forhold til en bibeltekst og et tema, og hvad forholdet er mellem de to præsenterede tilgange og modeller.

\section{RELIGIONSDIDAKTISK FORSKNINGSPOSITION}

I nordisk religionsdidaktisk forskning bliver de personlige og eksistentielle dimensioner jævnligt diskuteret. Andreassen argumenterer for, at en religionsvidenskabelig religionsdidaktik bør «nedtone religionsfagets eksistentielle orientering» (Andreassen 2012: 19), mens Skeie peger på, at læreplanen (i Norge) forudsætter, at faget skal bidrage til personlig udvikling. I hans forståelse handler arbejdet med den personlige og eksistentielle dimension om at «øve sig $i$ å stille spørgsmål om livet og de erfaringer mennesker gjør, samt å reflektere over de svar som mennesker kan gi på slike spørgsmål »(Skeie 2017: 128). Hovdenak og Leganger-Krogstad har udviklet en religionsdidaktisk model over akserne tid (vertikalt) og rum (horisontalt) til analyse af elevudsagn. Denne forbindes med fem forskellige tilnærmninger (tilgange) til religionsundervisning, som skal give eleverne mulighed for at orientere sig langs forskellige virkelighedsdimensioner, herunder en «Eksistentialistisk, filosofisk tilnærmning» (Hovdenak og LegangerKrogstad 2018). Hvor deres fokus er elevernes udsagn om undervisningen, er vores interesse lærernes (og de lærerstuderendes) planlægning og udvikling af religionsdidaktik. En væsentlig iagttagelse i deres analyser er, at en tekstorienteret tilgang er den, som står svagest i undervisningen (Hovdenak \& Leganger-Krogstad 2018: 39).

I international og norsk religionsdidaktisk forskning bruges Klafki undertiden til at legitimere en bestemt religionsvidenskabelig og «kritisk» tilgang til religionsundervisningen (Alberts 2007: 63-69, Andreassen 2010: 78f., Andreassen 2012: 39f., 208f.). Det sker altovervejende med udgangspunkt i den sene Klafkis teori om epokale eller tidstypiske nøgleproblemer og med fokus på et alment dannelsesbegreb, der vedrører kritik og frisættelse. Denne type tilgang overser myndighed 
som det centrale dannelsesbegreb og knytter dermed ikke an til den dannelsesteoretiske tradition ( $\mathrm{fx}$ Kant og Benner). Tilgangen forholder sig hverken til, hvad Klafki specifikt siger om religion i den sene almene dannelsesteori eller i relation til den kategoriale dannelsesteori i de tidlige værker. Religionens fremtrædende plads i den tidlige Klafkis almene dannelsesteori udelades tilsvarende i denne reception, som derfor bliver ensidig og unuanceret.

I artiklen vil vi belyse det dannelsespotentiale, som ligger i arbejdet med religiøse tekster. Det betyder ikke, at vi argumenterer for en religionsundervisning, som alene fokuserer på skriftlige kilder, men valget af en bibeltekst som didaktisk eksempel er bevidst i den forstand, at vi gerne vil insistere på, at arbejdet med kildetekster fortsat bør være et centralt element i religionsundervisning. Det er da også tilfældet i det danske skolefag, Kristendomskundskab, som omfatter fire hovedområder: bibelske fortællinger, kristendom, livsfilosofi og etik samt ikkekristne religioner og andre livsopfattelser (Børne- og Undervisningsministeriet 2019). Samtidig er den eksistentielle dannelse betonet i fagets formål gennem begrebet 'den religiøse dimension', som forbindes med det at spørge til livets mening (jf. Juul 2020).

\section{Almen didaktik som religionsdidaktik}

Som nævnt er Nielsens didaktiske begreb om relationsfeltet alment og stammer fra Wolfgang Klafki. Nielsen tager det fra en tidlig udgave af Dannelsesteori og didaktik - nye studier (Nielsen 2004: 38, Klafki 1985: 36f.), men begrebet kan også lokaliseres i de senere udgaver, både på dansk og tysk:

Enkeltvidenskaberne udvikler ikke i sig selv tilstrakkelige udvolgelseskriterier, selv om didaktiske beslutninger naturligvis ikke kan treeffes uden hensyn til de videnskaber, de referever til. Fagdidaktikker må som selvstondige videnskabelige discipliner udvikles $i$ greenseområdet eller bedre $i$ relationsfeltet mellem den almene didaktik og fagvidenskaberne.

Relationsfeltet er altså det felt, hvor fagvidenskaber og almen didaktik mødes ligeværdigt. Klafki udfolder ingen systematik eller teori om begrebet, som kun forekommer denne ene gang i Nye studier. Nielsen forholder sig til begrebet og bruger det systematisk til at integrere den almene didaktik med musikdidaktikken i en almen musikdidaktik (Nielsen 1998 [1994]).

Relationsfeltet repræsenterer et alternativ til to paradigmer: nedsivning og non-relation. I nedsivningsparadigmet sker der en uformidlet og ureflekteret kondensering af indhold og metoder, der siver ned fra basisfag til undervisningsfag. Med «basisfag» mener Nielsen «det fag eller den faglige virksomhed, der 
fungerer som den faglige basis for undervisningsfaget» (Nielsen 2004: 36). I den almene religionsundervisnings tilfælde er det både religionsvidenskab og teologi. Idealet i nedsivningsparadigmet er at gen- eller videregive et basisfags indhold og metoder i en så vidt mulig uændret form, uden «pædagogisk og vel også fagligt relaterede kriterier for væsentlighed» (ibid.: 37).

I non-relationsparadigmet frakobles basisfag fra fagdidaktikken og den faglige undervisning ud fra rene relevans-, menings og aktualitetshensyn. Idealet er her at skabe en undervisning med bedst mulig anknytning til eleverne, deres liv og erfaringer og den verden og tid, de lever i. Det sker «uden om det faglige i disciplineret forstand», hvilket indebærer en risiko for, at «forbindelsen mellem fag og didaktik i realiteten bliver blokeret» (ibid.). Det er heri, det non-relationelle består.

Relationsfeltet repræsenterer et alternativ til disse to paradigmer. Sammenhængen mellem fag og didaktik etableres ved at formulere pædagogiske kriterier for væsentlighed og forbinde dem med det faglige i disciplineret forstand. Det handler med lidt andre ord om «en fagliggørelse af den almene didaktik og en almengørelse af fagdidaktikken» (Illum Hansen \& Skovmand 2011: 239).

Denne dobbeltbevægelse mellem det faglige og det almene kan illustreres via to akser, der forbinder Nielsens fire kriterier for indholdsvalg, som han også betegner «didaktikker»: basisfags-didaktik, udfordrings-didaktik, etno-didaktik og eksistens-didaktik (Nielsen 2004: 27f.). I kort form kan kriterierne karakteriseres, som vi gør herunder.

Basisfags-didaktikken: Basisfagets struktur og indhold overføres til undervisningsfagene i en principielt uændret, men kondensert form.

Etno-didaktikken: Undervisningens udgangspunkt er elevkultur og elevernes hverdagserfaringer på mikrokulturelt niveau.

Udfordrings-didaktikken: Udgangspunktet er problemorienteret og tværfagligt i form af makrokulturelle, samfundsmæssige problemstillinger (fx Klafkis epokale nøgleproblemer).

Eksistens-didaktikken: Undervisningen orienterer sig imod «menneskets eksistentielle grundvilkår».

Disse didaktikker udelukker i udgangspunktet ikke hinanden, men «udgør hinanden supplerende synsvinkler på det samme fænomen, nemlig perspektiver på bestemmelsen af hvad (d.v.s. hvilket indhold) der er væsentligt i den almene undervisning og dannelse» (ibid.: 28). En sådan tilgang til undervisningen vil således udelukke en både rent eksistentiel religionsundervisning og en ren religionsvidenskabelig.

I en fortolkende brug af Nielsens systematik kan man stille de fire kriterier op over for hinanden $i$ en model (se næste side).

Jf. Nielsens egen bemærkning om, at kriterierne bør supplere hinanden, må man opfatte dem som principielt lige vigtige «i den almene undervisning og 


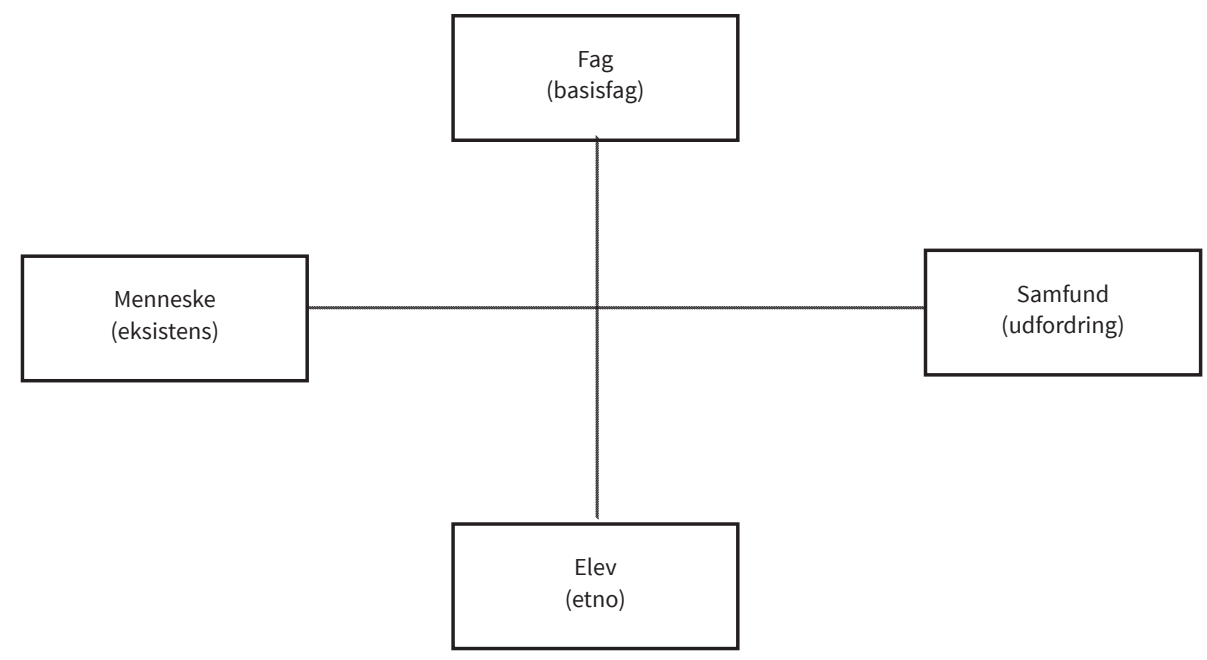

Figur 1: Forholdet mellem de fire kriterier for indholdsvalg hos Frede V. Nielsen

dannelse». I basisfags-didaktikken er undervisning og dannelse ikke almen. I de andre -didaktikker, som på forskellig vis kan repræsentere noget alment, risikerer undervisning og dannelse at blive afaglig.

Modellen udløser overvejelser over, hvordan de fire kriterier supplerer hinanden, og hvad forholdet er mellem dem. Den giver også anledning til at tænke relationsfeltet som et krydsfelt. Det afgørende er ikke feltet af relationer, men det krydspunkt i modellens midte, hvor akserne brydes, og de fire kriterier potentielt forenes.

\section{Didaktisk bearbejdning af vingårdslignelsen}

Går man et skridt videre i en fortolkende brug af Nielsens systematik, kan man tilføje en «kode» til hvert af de fire kriterier. Basisfags-didaktikken rejser spørgsmålet om sandhed, udfordrings-didaktikken vedrører aktualitet, etno-didaktikken rejser relevansspørgsmål, og endelig handler eksistens-didaktikken om meningen med tilværelsen. Hvis man forbinder kriterier og koder giver det anledning til formuleringen af en overordnet didaktisk målsætning og forpligtelse for grundskolens undervisning, som er at toenke, tilrettelogge og realisere undervisningshandlinger, som er sande, aktuelle, relevante og menneskeligt meningsfulde for eleverne.

Man kan illustrere anvendelsen af disse kriterier og koder ved hjælp af Lignelsen om arbejderne $i$ vingården (Matt 20,1-16). I lignelsen ydes der lige løn for ulige indsats. En vingårdsejer hyrer arbejdere fra tidlig morgen til dagens ellevte time. De arbejdere, der tjener vingårdsejeren hele dagen, får den samme betaling som de arbejdere, der kun tjener en time. Betalingen er én denar, uanset arbejdernes 
indsats. De arbejdere, der «har båret dagens byrde og hede», giver «ondt af sig», fordi de mener, at de har gjort sig fortjent til mere end dem, der kun har arbejdet en enkelt time. De forurettede arbejdere sendes bort med en besked om, at de har fået som aftalt, og at de derfor ikke skal give ondt af sig. De sættes på plads med en slutreplik om, at «sådan skal de sidste blive de første, og de første de sidste».

Lignelsen illustrerer menneskets forhold til Gud. Arbejdsdagen i vingården er et billede på livet, og afregningen ved dagens ende modsvarer billedligt overgangen til efterlivet. Ingen kan retfærdiggøre sig over for Gud, når regnskabet skal gøres op, og optagelsen i Guds rige er ikke et spørgsmål om, hvem der kom først til tro og har ydet mest. Alle stilles med den samme ene denar lige over for Gud, samtidig med at selvretfærdigheden problematiseres, og slutreplikken sår tvivl om ligheden.

I nedenstående skema anvender vi de skitserede kriterier og koder på vingårdslignelsen. Herved bliver det tydeligt, at der knytter sig forskellige typer af sprog til de fire bindstregs-didaktikker. Det viser sig også, at et bestemt indholdskriterie lægger et bestemt tematisk perspektiv fast ved at gøre en indholdskategori til den grundlæggende. Indholdsvalg vedrører ikke kun et overordnet valg af fx bibeltekst eller lignelse, men er måske væsentligst et valg af indhold i den tekst, der skal arbejdes med i undervisningen. Grundkategorierne i skemaet er udtryk for et indholdsvalg.

Figur 2: Kriterier, koder, sprog og kategorier i relation til Lignelsen om arbejderne i vingården

\begin{tabular}{|c|c|c|c|c|}
\hline Didaktik & Basisfags- & Etno- & Eksistens- & Udfordrings- \\
\hline Kode & Sandhed & Relevans & Mening & Aktualitet \\
\hline Sprog & Videnskabeligt & Personligt & Religiøst & Alment \\
\hline Grundkategori & Guds rige (eskatologi) & Misundelse & Tro (retfærdiggørelse af) & Sociale rettigheder \\
\hline
\end{tabular}

Alle fire -didaktikker er utilstrækkelige og mangelfulde i sig selv. Hvis vi (basisfags-didaktisk) reducerer teksten til at være et eksempel på en tekst om Guds rige, dvs. en eskatologisk tekst, ser vi bort fra, hvad den i øvrigt er - og kan bringes til at handle om i undervisningens fortolkningsfællesskab. Hvis vi omvendt (etnodidaktisk) gør lignelsen til en tekst om misundelse og ser bort fra, at den handler om døden og dommen og også om en guddommelig udfordring af et menneskeligt retfærdighedsprincip, går vi også galt i byen. Hvis vi (udfordrings-didaktisk) blot ønsker at aktualisere teksten, risikerer vi at forfalske den.

Den tyske didaktiker Andreas Gruschka taler om «forfalskning gennem aktualisering» og bruger netop undervisningen i denne bibeltekst som eksempel. Forfalskningen foregår dels ved, at teksten slet ikke læses, men i stedet «medietransponeres» til et hørespil, dels ved at den bringes til at handle om aktuelle 
forhold på arbejdsmarkedet: «Der optræder en fortæller, der beretter om sin underlige chef, som ikke behandler sine ansatte ens» (Gruschka 2016: 61). Teksten bliver «verdsligt aktualiseret», idet målet er «at drage en forbindelse mellem den guddommelige retfærdighed og sekulære tanker om ejendommens sociale forpligtelser» (ibid.). At teksten handler om menneskets forhold til Gud (og sine medmennesker), og problematiserer menneskets målestok for retfærdighed, som baserer sig på fortjeneste, lades i denne verdslige aktualisering ude af betragtning. Dermed sker der en forfalskning. Den fagdidaktiske udfordring bliver at aktualisere teksten uden at forfalske den.

I en grundigere analyse peger Gruschka på, at lignelserne kan karakteriseres som didaktiske tekster, der stiller de troende «refleksionsopgaver», der er paradoksalt konstrueret, fordi de forkynder et bestemt budskab på en måde, som tilhøreren eller læseren selv må opdage (Gruschka 2009: 457). Lignelserne tager udgangspunkt i hverdagen og det velkendte, men vil sige noget om evigheden og det ukendte via et særligt billedsprog. Lignelserne har et bestemt, om end ofte tvetydigt, religiøst budskab, som undervisningen skal afdække og omsætte. Gruschka peger på et treleddet hermeneutisk problem. Teksten må erfares og erkendes som 1) en meningsfuld helhed på sine egne betingelser, 2) et billede på Guds rige, og 3) et budskab, der kan overføres til læserens egen livsførelse (ibid.: 458). Hermed indtager Gruschka en eksistens-didaktisk position med en basisfaglig forankring, fordi der ud fra en tolkning af teksten rejses spørgsmål om mening.

Den fagdidaktiske udfordring kan tages op ved at gøre netop «retfærdighed» til tema. Ordet er ikke indeholdt $\mathrm{i}$ lignelsen, men begrebet tematiseres tydeligvis. Som nævnt handler teksten om forholdet mellem den guddommelige retfærdighed, der tilsiger, at alle skal have det samme, uanset hvad de har ydet (alt for intet), og den menneskelige retfærdighed, der vil, at vi alle får efter fortjeneste (noget for noget). Alle arbejderne får en denar, uanset om de har tjent $i$ vingården 11 timer eller blot en enkelt. Lignelsen stiller et gratisprincip over for et belønningsprincip. Gratis betyder egentlig af nåde. Gratis var det ord, Martin Luther brugte om troen, som han mente, at man fik for ingenting.

Vi har i de nordiske velfærdsstater sociale rettigheder (jf. skemaet ovenfor), der sikrer alle ligeligt på samme måde, som det guddommelige retfærdighedsprincip i lignelsen gør. Det er med velfærdsstaten, som det er med Guds rige, kunne man næsten sige. Det er med sygesikringskortet som med den ene denar. Det betyder ikke, at vi skal takke en kristen kulturarv (eller en gud for den sags skyld) for velfærdsstatens gaveregn, men blot at vi skal pege på, at der er en virkningshistorisk sammenhæng mellem et religiøst og et socialt grundprincip, som viser sig på et bestemt tidspunkt i det sociale livs historie i Skandinavien, hvorfra grundprincippet kan forsvinde igen.

Der sker en didaktisk transformation af basisfaglig viden, fordi konteksten 
ændrer sig. Den akademisk disciplinerede viden foreligger i en forholdsvis statisk form, der kan genfindes i lærebøger og faglitteraturen. Denne viden kan formidles ind i et undervisningslokale. Sker det uformidlet, er der tale om nedsivning, men i relationsfeltet sker der en forvandling af faglig viden, idet denne viden almengøres. I forhold til vingårdslignelsen er det vigtigt, jf. også Gruschkas treleddede lignelseshermeneutik, at trænge ind til de erfaringer, der ligger bag eller i teksten.

Ét er den almene erfaring af arbejdsvilkårene i en vingård på Jesu tid, som teksten udtrykker, noget andet er den religiøse erfaring af de helt omvendte erfaringer i Jesu forkyndelse af Guds rige. Ét er repræsentationen af disse erfaringer i teksten, noget andet er repræsentationen af fortolkninger af teksten som fx Lucas Cranachs kendte skildring af vingården i Mariekirken i Wittenberg, der i virkeligheden er en illustration af Luthers retfærdiggørelseslære og et opgør med den katolske kirkes gerningsretfærdighed.

\section{Didaktisk transformation}

Den didaktiske transformation bliver tydelig, når vi spiller lignelsen ud imod udfordrings-didaktikken og etno-didaktikken og spørger til dens mulige aktualitet og relevans. Sådanne spørgsmål ligger uden for videnskabernes horisont, men er uundgåeligt en del af undervisningens kontekst, fordi teksten skal tale til eleverne og ind i en tid. Der sker med Basil Bernsteins begreb en «rekontekstualisering» af faglig viden og teori i den pædagogiske diskurs (Bernstein 2001), hvorved «både viden og teori forandres i mødet med hinanden - og af mødet med studerende og elever i undervisningssituationen» (Illum Hansen \& Skovmand 2011: 276). Det faglige indhold bliver gjort til undervisningsindhold, den faglige viden repræsenteres ud fra en «pædagogisk anordning», der underlægger viden og indhold et dannelsesformål (Bernstein 2001: 165).

Når vi gør retfærdighed til almen grundkategori i den didaktiske analyse af vingårdslignelsen, indfinder den sig i midten af relationsfeltet der, hvor de to akser krydser hinanden. Man kan se modellen som en fortolkning eller en illustration af Klafkis kategoriale dannelsesteori, fordi retfærdighed er den kategori, der formidler en dobbeltsidig åbning (Klafki 1975 [1963]: 43f.). Retfærdighed åbner således op for en integration af modellens fire aspekter, hvor forholdet mellem fag og elev er udspændt på den horisontale akse. Basisfagligt handler det, jf. også Gruschka, om at læse teksten på dens egne præmisser og som bærer af et særligt retfærdighedsbudskab, som relateres til barnets retfærdighedsforståelse. Samtidig handler det om at reflektere disse forskellige former for retfærdighed både eksistentielt og politisk i forhold til nutiden.

Anderledes formuleret er lignelser «dannelsesindhold», dvs. det særlige indhold, der eksemplarisk viser hen til og udtrykker noget alment (dannelsessubstans). Klafki skriver, at «talrige bibelske fortællinger eller lignelser er variationer 
af en stor trossandhed, som i sidste instans er den ene kristne trossandhed» (Klafki 1975 [1963]: 121). Pointen er, at trossandheden er utilgængelig i en ren almen form. Den må vises og eksemplificeres. Spørgsmålet er, om den enkelte tekst ikke snarere er et eksempel på en genre, således at man fx udvælger tre forskelligartede lignelser som eksempler på genren og lader trossandheden være pluralistisk.

Problemet er, at Klafki forudsætter, at der kun er én trossandhed. Konfessionerne er netop variationer af en måske nok stor, men også pluralistisk «trossandhed». Kristendommen er med andre ord en pluralistisk trospraksis. Tilsvarende bør undervisningens fortolkningspraksis være pluralistisk. Eleverne skal netop, jf. Gruschka, selv tage stilling til, hvad de i deres liv vil stille op med budskabet i en lignelse, men det kræver, at de har fortolket den først.

Dannelsesindholdet får dermed en dobbelt betydning. Det er både det eksemplariske indhold, der viser hen til noget alment, men er samtidig det indhold, som eleverne skal dannes alment af, «en genstand, den unge person kan gøre til sin åndelige ejendom» (ibid. 129) Ifølge Klafki skal det ske via selvvirksomhed, hvilket indebærer, at eleven «kan tilegne sig forskellige spørgeretninger og veje til selvstændig overvindelse af konkrete problemer» (ibid.: 41). Ifølge Gruschka er det et krav til «organiseringen af selvvirksomhed», at den «bestemmes ud fra de konkrete opgaver til emnet» (Gruschka 2016: 123). Dannelsesindhold er sammenfattende sagt eksemplarisk udvalgt viden, der kan tilegnes og tolkes pluralistisk.

\section{DiDAKTIK OG DANNELSESTEORI}

Når der skal udsondres kriterier for indholdsvalg i undervisningen, er det ikke tilstrækkeligt at forsøge at etablere forbindelser mellem basisfaglig viden på den ene side og elevernes forudsætninger og erfaringer på den anden. Den basisfaglige viden skal medieres og reflekteres af almene kategorier, der undersøges via det faglige stof. Det er blandt andet det, der ligger i Klafkis kategoriale dannelsesteori og begrebet om den dobbeltsidige åbning, som vi eksemplificerede med kategorien retfærdighed.

\section{Religion som del af den almene dannelse}

Men det er ikke gjort med det. Som sagt er undervisningen underlagt et alment dannelsesformål. Klafki gør to ting gældende. Dels skal den almene undervisning foregå inden for «den dannede lægmands spørgsmåls- og forståelseshorisont», dels er «et skolefag eller et dannelsesområde konstitueret af flere betydningsprincipper» (Klafki 1975 [1963]: 129, 118). Lægmandsperspektivet vedrører den almene dannelse, som er grundlaget for, at «vi alle kan finde os til rette $i$ den virkelighed, der ligger uden for vore specifikke erhverv» (ibid.: 108). Klafki skelner mellem syv roller. De to første er «den oplyste samtidige» og «den religiøse lægmand», som han ikke sætter mange ord på. Tilsvarende skelner han mellem 
fem konstituerende betydningsprincipper, hvoraf det sidste er religiøst - egentlig en «religiøs betydning», der rækker ud over de fire første «dennesidige betydningsprincipper» (det etiske, æstetiske, teoretiske og pragmatiske). Der peges her på en substantiel sammenhæng mellem den almene dannelse og dannelsen til religiøs lægmand (og dermed til religiøs myndighed), men i virkeligheden også på den betydning, religion har for og ud over en dennesidig betydningsdimension.

Hos den tidlige Klafki spiller religion eller religiøsitet med andre ord en central rolle i forståelsen af, hvad almen dannelse er, og hvad der konstituerer et skolefag eller dannelsesområde. Hos den sene Klafki er det udviklingen af barnets evne til selvbestemmelse, medbestemmelse og solidaritet, der er afgørende. Evnen til selvbestemmelse handler om «egne, personlige levevilkår og livsanskuelser af medmenneskelig, erhvervsmæssig og religiøs art» (Klafki 2011 [1996]: 122). Religiøse livanskuelser sidestilles her med medmenneskelige og arbejdsmæssige, men religion optager generelt ikke nogen central plads i dannelsestænkningen hos den sene Klafki. Dog peger han på sekulariseringen som en «central bestemmelse af det borgerlige samfund», men pointerer samtidig: «Religionsfjendtlighed er på ingen måde en nødvendig konsekvens» (ibid.: 30). For Klafki indeholder dannelsesbegrebet myndighedsbegrebet, idet det indebærer «ethvert menneskes ret til og mulighed for at nå frem til en selvbestemmelsesevne» (ibid.: 119). Selvbestemmelse er en anden måde at sige autonomi på.

\section{Religion og myndighed}

Hvis vi forbinder religion med kategorier som afhængighed, lydighed eller underkastelse, tegner der sig et spændingsforhold mellem autonomi og religion, der synes at udelukke eller vanskeliggøre religion i et sekulariseret samfund. Forestillingen om religiøsitet som det modsatte af selvbestemmelse og myndighed har baggrund i oplysningens tænkning og de stærke sekulariseringsteorier, som indebar en forestilling om, at religion gradvist ville blive fortrængt (Furseth \& Repstad 2007: 137). Immanuel Kant definerede i 1784 oplysning som «menneskets udgang af dets selvforskyldte umyndighed» og forklarede umyndighed som «manglen på evne til at betjene sig af sin egen forstand uden en andens ledelse» (Kant 1993 [1784]: 71). Hos Kant er myndighed knyttet til fornuft, og i en klassisk sociologisk sekulariseringstese fører moderniteten til en udfasning af det religiøse, fortrængt af en større fornuft, videnskab og selvberoende individer, der er frigjort fra religionernes patriarkalske og hierarkiske verdensopfattelse (Uljens 2008: 55f.).

Fra slutningen af det 20. århundrede er sekulariseringstesen som bekendt blevet kritiseret og nuanceret ud fra en erkendelse af, at religion ikke er blevet udfaset, men derimod har ændret betydning i kraft af pluralitet og individualisering (jf. Sigurdsson 2007). Nogle teorier skelner mellem sekularisering på forskellige niveauer som samfund, organisation og individ (Dobbelaere 2002), 
andre anvender begrebet det postsekulære samfund til at pointere, at refleksion, tilpasning og selvkritik bliver en fordring for religiøse såvel som ikke-religiøse borgere inden for rammen af religionsfrihed og princippet om lighed (Habermas 2009). Forskellige religioner og livsanskuelser er principielt ligestillede, og religion bliver et blandt flere differentierede og relativt uafhængige systemer.

\section{Religion som fællesmenneskelig handleform}

Hos den tyske dannelsesfilosof Dietrich Benner kommer differentieringen til udtryk i teorien om en almen pædagogik og prakseologi. Prakseologien er en teori om fællesmenneskelig praksis. I Benners prakseologi dannes mennesket i seks fællesmenneskelige praksisfelter: arbejde, kunst, etik, politik, opdragelse og religion (Benner 2001: 44). På opdragelsens område er det karakteristisk for demokratiske samfund, at «nye mennesker ikke må frembringes ved statens mellemkomst og det politisk nye ikke gennem opdragelse» (Benner 2005: 82). I moderne demokratiske samfund er de seks felter sideordnede, sådan at ingen af dem kan hæve sig op og indtage en dominerende position over de andre.

De pædagogiske processer må knytte an til barnets dannelsesåbne natur, dets formbarhed (Bildsamkeit), og sigte mod, at barnet kommer til at vekselvirke med verden og danne sig gennem selvvirksomhed, jf. også Klafki. Benner ser barnet som åbent både med hensyn til sin selvbestemmelse og $\mathrm{i}$ forhold til fremtidige fællesskaber og opgaver (Oettingen 2007: 63). Formålet med undervisning er således ikke at «affirmere» (dvs. bekræfte) en bestemt identitet, men derimod ikke-affirmativt at skabe rum for elevernes erfarende, handlende, undersøgende og reflekterende omgang med verden, sådan at det opvoksende menneske selv bliver i stand til at agere myndigt inden for praksisfelterne (Andersen \& Sigurdsson 2020: 204).

At skolens undervisning og dannelsesarbejde ikke bør være affirmativt, betyder, at skolen må afholde sig fra at bekræfte positiviteter, der er givne på forhånd (en ideologi fx). Religionsundervisningen kan derfor hverken være «religionsvenlig» (før-kritisk) eller «religionsfjendtlig» (kritisk), men må overskride modsætningen mellem det før-kritiske og det kritiske fra en efter-kritisk position, der reflekterer forholdet mellem det før- og det efter-kritiske uden at tilslutte sig den ene af de to positioner (Skovmand 2007). Ifølge Benner må en pædagogisk begrundet religionsundervisning være baseret på to antagelser. Den første er, at den religiøse meningshorisont er væsentlig for at forstå menneskelig eksistens og sameksistens (Benner 2005: 84). Religion er en antropologisk «nødvendighed», fordi der er en nød, der skal vendes, i og med at mennesket skal forholde sig til døden. Prakseologien er slet og ret «et ikke-hierarkisk system for alle samfundsmæssigt nødvendige former for virksomhed» (Benner 2005: 61). Den anden grundlæggende antagelse er begrundet netop i prakseologien: Religion har ingen forrang frem for de øvrige praksisfelter - fx etik og politik som de måske mest nærliggende. 
Imidlertid er der en potentiel spænding mellem åndsfrihed og normative interesser, som især viser sig inden for den politiske, etiske og religiøse dannelse (Oettingen 2010). Her kan dannelse ikke bestå i at bekræfte et bestemt menneskeeller samfundssyn, men undervisningen skal sætte rammer for, at eleverne kan deltage i refleksion, diskussion, kritik og handling. Der må være fokus på menneskets søgen efter mening, men der skal ikke lægges op til bevidstløse accept af en allerede fastlagt norm (Oettingen 2007: 63). Kun således kan undervisningen undgå at blive affirmativ.

Religionsundervisning er særligt kendetegnet ved at finde sted $i$ et normativt spændingsfelt, men rummer i en sekulariseret sammenhæng også en anden stor udfordring. Vi kan ikke længere forudsætte, at eleverne har erfaringer med religion, og religiøse begreber og praksisformer vil for nogle derfor være en fremmedverden, som først skolen fører dem ind i. Det handler derfor om, at «bevidstgøre afbrudte traditioner og traditionsbrud og at erindre disse i processen med at udvikle nye traditioner» (Benner 2005: 24).

Derved bliver det en didaktisk opgave at overveje, hvordan vi i undervisningen tematiserer et religiøst indhold, som nogle elever slet ikke har levede relationer til (Oettingen 2010: 109; Andersen \& Sigurdsson 2020: 257). Skønt vi ofte forudsætter, at vi lever i et multikulturelt samfund, er det måske mere præcist at tale om et spektrum af forskelle i henholdsvis tilslutningen til og tabet af traditioner. I forhold til religionsdidaktikken gør traditionsbrud både etno- og eksistens-didaktikken til potentielt problematiske afsæt, fordi der mangler fagligt relevante erfaringer at knytte an til, og den eksistentielle meningsdannelse ofte finder sted uden anknytning til religiøst sprog. Anknytningen til elevernes almene erfaringer og sprog risikerer at blive afaglig.

Som det fremgår, er myndighedsbegrebet omdrejningspunkt for den prakseologiske tænkning, ligesom det også er hos Klafki. Benner forstår myndighed som «menneskets evne til at reflektere sin egen livsførelse og til at kunne tage stilling til såvel denne som til det fællesmenneskelige livs former» (Benner \& Brüggen 2011: 687). Pluralitet er en præmis. Det moderne samfund udviser «en pluralitet af forskellige tydningsmønstre, livsanskuelser og livsformer», og myndighed er blandt andet evnen til at være kritisk i denne kontekst af pluraliteter og tage del $\mathrm{i}$ «en eksperimenterende og innovativ omgang med det egne og det fremmede» (ibid.: 698f.).

\section{DANNELSE TIL MYNDIGHED I}

RELIGIONSPEDAGOGISK PRAKSIS

I et aktionsforskningsprojekt om religionsdidaktik i skole og kirke blev myndighed diskuteret og afprøvet som religionspædagogisk begreb. Projektets sigte var udvikling af religionsdidaktik via samarbejde med erfarne praktikere i 
en ramme, som forbinder dannelsesteori med praksisviden. I overensstemmelse med aktionsforskningens principper definerede hver deltager et undersøgelsesfelt og tilrettelagde en undervisningsaktion, som siden blev gjort til genstand for refleksion og justering. Styrken ved aktionsforskning som metode er det tætte samarbejde mellem praktikere og forskere, som giver mulighed for at komme tættere på undervisningens kompleksitet og den praksisviden, som erfarne lærere er bærere af. Metoden bygger på en ligeværdighed mellem praktikere og forskere, sådan at arbejdsformen også bidrager til en myndiggørelse af deltagerne (Andersen \& Sigurdsson 2020: 33; Skeie 2010: 146). Samtalerne i de to adskilte praksisfællesskaber og den efterfølgende analyse af de i alt otte forløb ledte til udarbejdelsen af en krydsmodel over dannelse til religiøs myndighed (Andersen \& Sigurdsson 2019a; Andersen \& Sigurdsson 2019b; Andersen \& Sigurdsson 2020). Modellen afspejler derfor samtaler om og analyser af undervisningsforløb belyst og analyseret gennem dannelsesteori.

Dannelse til religiøs myndighed handler ikke om forvaltning eller udøvelse af religiøs myndighed og heller ikke om dannelse til en specifik religiøs identitet. Begrebet skal derimod betegne en dannelse, som tager afsæt $i$ et nuanceret og differentieret blik på religion i det senmoderne samfund. Det indebærer en fordring om at knytte religionsundervisningen an til et dannelsesformål, sådan at den kan medvirke til selvvirksomhed og befordre tænkning, dømmekraft og selvstændighed - også i forhold til religion og mulige trosvalg. Dermed bliver forehavendet ikke blot dannelsesteoretisk, men også didaktisk.

Modellen er tænkt som et redskab til didaktisk planlægning, analyse og refleksion, hvor myndighed er horisont for dannelsen. Det er ikke tanken, at alle fire aspekter skal være ligeligt repræsenteret $\mathrm{i}$ alle undervisningsforløb, men at læreren eller den studerende i sin planlægning og evaluering af hvert forløb kan overveje koblinger til et eller flere aspekter og $i$ den samlede årsplan se på forholdet imellem dem. Lodret og vandret er modellen struktureret som to punkter på en akse. Samtidig tegner de to akser et kryds, som etablerer fire didaktiske rum med forskellige betoninger. Modeller giver et overblik over didaktiske problemstillinger og sprog for dannelsens kompleksitet.

Modellen har samme grundform som relationsfeltsmodellen. Der gælder også den samme fordring om krydspunktsintegration af de to akser og refleksion over forholdet mellem de fire aspekter og didaktiske rum. Samtidig rejser den andre typer af spørgsmål. Hvert aspekt kommer til udtryk i et spørgsmål, som retter sig mod undervisningens praksis - dvs. både indhold, arbejdsformer og organisering.

Vi gengiver her spørgsmålene i en både almen og eksemplificeret form ved at indplacere vingårdslignelsen i modellen og kort skitsere, hvordan den kan anvendes i et tematisk forløb om retfærdighed. 


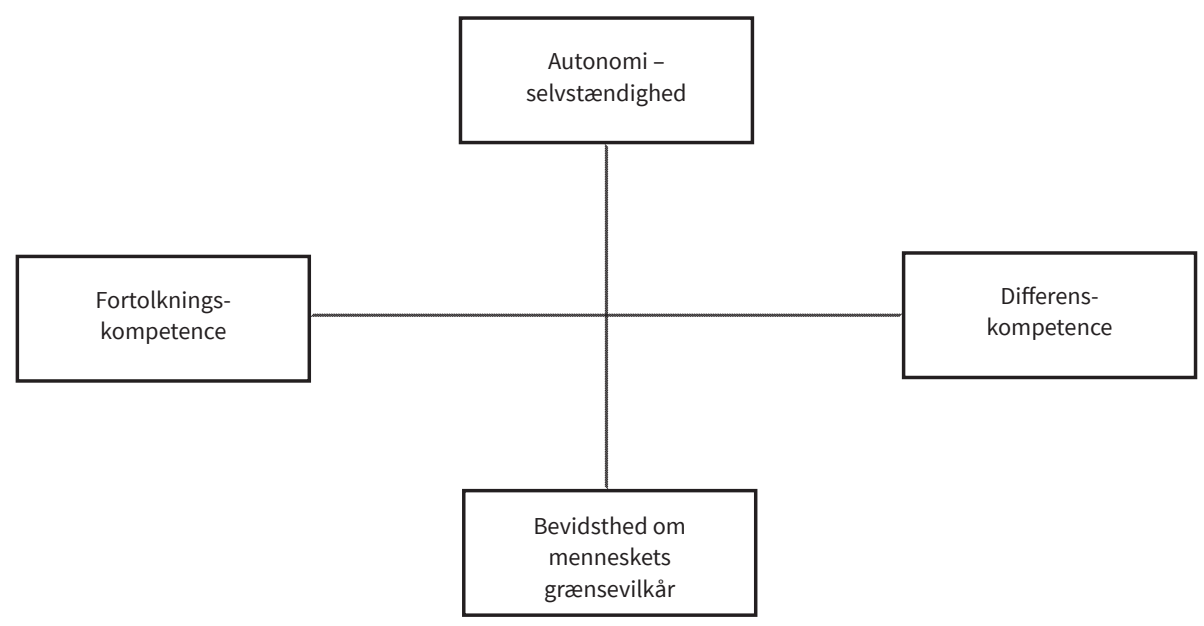

Figur 3: Dannelse til religiøs myndighed

1 Autonomi/Selvstondighed: Hvordan bidrager undervisningen til udvikling af selvbestemmelse, ansvar og evne til at indgå i foellesskaber som et selvstcendigt individ?

Undervisningen i Lignelsen om arbejderne i vingården kan tematisere forholdet mellem individ og fællesskab. Hvad er forholdet mellem, hvad jeg selv gør og får, og de andres indsats og belønning? I hvilken udstrækning skal jeg være solidarisk med dem, som ikke kan gøre krav på det samme som mig? Hvilket blik ønsker jeg, at andre skal have på mig? Er det naturligt, at nogen føler misundelse, hvis der finder forskelsbehandling sted? Er forskelsbehandlingen retfærdig? Spørgsmål som disse lægger op til arbejdsformer, som giver eleverne mulighed for selvstændig refleksion med teksten. I et tematisk forløb om retfærdighed kan tekstarbejdet følges op med fx filosofisk undersøgelse af og samtale om retfærdighed som begreb.

2 Bevidsthed om menneskets gransevilkår: Hvordan bidrager undervisningen til undersøgelse af og refleksion over menneskets gransevilkår?

Lignelsen er en grænsetekst. Den handler om død og dom og rejser tvetydige spørgsmål om, hvad kriterierne er for, om mennesket kommer i Guds rige (dvs. bliver frelst), når det dør. Døgnet er delt i to, ligesom livet. Arbejdsdagen er som livet og lyset. Der markeres med afregningen en overgang til enten nyt ophøjet liv og lys eller definitiv død og medfølgende mørke. Lignelsen lader det stå åbent, om den universelle lighed, der udvises, også er et udtryk for universel frelse, eller om de knurvorne daglejere, der fandt vej til vingården først på dagen og finder ligestillingen urimelig, ender med at blive frelst. «Sådan skal de sidste blive de første, og de første de sidste», lyder det til sidst. 
Hvad betyder det? Hvem ender med at være sidst? Tekstens eskatologiske forestillinger kan ligge langt fra elevernes dagligdag, men ved at knytte an til lignelsernes funktion som refleksionsopgaver (jf. Gruschka) kan læreren tilrettelægge opgaver, som gør brug af tekstens åbenhed og tomme pladser (Illum Hansen \& Skovmand 2008) og i sammenhæng hermed introducere basisfaglige kategorier som dom og frelse.

3 Fortolkningskompetence: Hvordan bidrager undervisningen til udvikling af et fagsprog og differentieret evne til fortolkning ud fra både personlig refleksion og faglige begreber? Undervisningen i lignelsen udvikler både et fagsprog og tilbyder forskellige fortolkningsrum og -muligheder, når den fx er tænkt og tilrettelagt ud fra relationsfeltsmodellen. Den personlige refleksion handler om misundelse eller det modsatte, og om at kunne indtage forskellige modtagende positioner og selv gebærde sig i hverdagen (etno-didaktik). Det kan være spørgsmål om, hvorvidt vi kan overtage vingårdsejerens retfærdighedsbegreb og gøre det til norm for vores egne handlinger på en meningsfuld måde (eksistens-didaktik), men også om hvordan vi har indrettet vores velfærdssamfund og ønsker det indrettet (udfordrings-didaktik). Udvikling af fagsprog må understøttes af basisfaglige kategorier og viden $\mathrm{fx}$ om lignelser som genre og fortolkningsøvelser med inddragelse af historiske forhold vedrørende samfundsstruktur, magtforhold og forestillinger om retfærdighed.

4 Differenskompetence: Hvordan bidrager undervisningen til at udvikle en selvbevidst forskelsrefleksion, dvs. evne til at kommunikere om og håndtere forskelle både mellem religioner, inden for den enkelte religion og mellem religion og andre rationaler/ systemer?

Differenskompetencen udvikles i arbejdet med lignelsen via konfrontationen af modsætningen mellem to forskellige former for og principper for retfærdighed. Kan disse modsætninger forenes? Er der situationer og tilfælde, hvor den ene form for retfærdighed synes rimelig, og andre, hvor den forekommer forkastelig? Man kan skrue op for differenskompetencen ved at lade eleverne stille sig frit i mellemgruppernes sted: Hvad ville du tænke, hvis du havde været i vingården tre, seks, eller ni timer? Differenskompetence kan yderligere understøttes ved at inddrage domstekster og eskatologier fra andre religioner og derigennem lade eleverne undersøge variationer og konflikter mellem forskellige religiøse forståelser af retfærdighedsbegrebet.

Krydsmodellen over dannelse til religiøs myndighed kan ud over denne form for didaktisk detailanalyse også anvendes til analyse af en årsplan, et undervisningsforløb eller delelementer af et forløb (jf. analyserne i Andersen \& Sigurdsson 
2020). Det handler i alle tilfælde om at skabe sammenhæng og udveksling mellem akserne og at etablere en sammenhæng mellem didaktik og dannelseteori.

\section{Forholdet mellem akserne}

På den lodrette akse er der en spænding mellem to poler: På den ene side betegner autonomi det etiske ansvar og en frihed til selvbestemmelse, og på den anden side står de situationer i tilværelsen, som mennesket ikke selv har magten over. Den tyske psykiater og filosof Karl Jaspers introducerede begrebet grænsesituationer (Jaspers 1919 og 1931), og det er blevet stående som et centralt begreb i den eksistentielle psykologi (Mortensen 2008: 38). Det refererer til erfaringer af tab, tilfældighed, lidelse, død og skyld, hvor mennesket står afmægtigt over for livets modsigelsesfyldte struktur. I forlængelse af Hannah Arendts tolkning af menneskets vilkår kan fødsel og kærlighed også betragtes som grænsesituationer (Mortensen 2008: 25). I spændingen mellem de to poler kan religionsundervisningen yde et helt specifikt bidrag til dannelsen, fordi det religiøse sprog gennem myter, fortællinger og ritualer udlægger menneskets grænseerfaringer, ligesom religiøs og filosofisk tænkning belyser de potentielle konflikter mellem vilje og evne, magt og afmagt, selvbestemmelse og afhængighed (jf. Andersen \& Sigurdsson 2020: 213).

På den vandrette akse sættes fortolkningskompetence over for differenskompetence. Spændingen mellem de to poler etablerer blik for brydninger og mangfoldighed i religionerne både historisk og nutidigt. Fortolkningskompetence er evnen til at afkode, analyse og tænke over religiøse tekster og udtryk, altså en religiøs literacy, hvor eleverne udvikler et basalt kendskab til religiøse tekster og praksisformer og kan anvende faglige begreber til at analysere, fortolke og forholde sig til indholdet (jf. også den tredimensionale tilgang til fortællinger hos Breidlid og Nicolaisen 2011). Differenskompetence har betydning for dannelse til pluralitet og evnen til at begå sig i en mangfoldig verden. I kraft af brudt tradering og elevernes varierede forhold til religion som praksisform (jf. Benner) kan det være væsentligt at eleverne kan få øje på, hvordan de begrunder deres egen eksistenstolkning og livsførelse. Det indebærer dels et reflekteret forhold til egen tro, dels en evne til at forholde sig undersøgende og nuanceret til andres tro og tilhørsforhold (jf. Kristensen 2008). Differenskompetence lægger op til en engageret deltagelse i pluralitetens væv af menneskelige relationer med sans for livet som forskellig og unik eksistens blandt ligestillede (jf. Arendt 1958: 180).

\section{KONKLUSION OG PERSPEKTIVERING}

Artiklen har to konklusioner - eller måske snarere anbefalinger:

1 Religionsundervisningen skal repræsentere viden i en didaktisk reflekteret og omsat form for at sikre perspektivpluralisme og skabe alsidige møder mellem elev og verden via fag. 
2 Religionsundervisningen skal være pluralistisk og underlagt et alment dannelsesformål om myndighed, som gælder for al anden undervisningsvirksomhed i grundskolen.

Dette gælder i udgangspunktet for den almene religionsundervisning i grundskolen og for den undervisning i læreruddannelsen, der retter sig imod religionsundervisning i skolen. Når basisfaglig viden bringes ind i læreruddannelsen med henblik på at bringes videre ind i skolens religionsundervisning må den så at sige forstyrres af den pædagogiske anordning og den nye normative kontekst. Hvordan viden her transformeres i mødet med både didaktikken og dannelsesteorien, har vi vist med vingårdseksemplet. Denne transformation skal ikke først finde sted i skolen, men må allerede finde en plads i læreruddannelsen. Som undervisere af kommende lærere må vi selv foregå med et godt eksempel, selv foretage indholdsvalg, der afbalancerer forholdet mellem de fire -didaktikker, selv danne de studerende til religiøs myndighed ved at vise, hvordan vi selv er myndige. Hvordan gør jeg min undervisning i religion og religionsdidaktik på én gang sand, aktuel, relevant og menneskeligt meningsfuld?

De to modeller er en praktisk hjælp hertil, fordi de muliggør analyser af både fagligt indhold, pædagogisk praksis og didaktiske læremidler (Illum Hansen \& Skovmand 2011: 19). Snart sagt alt, hvad der sker i relation til religionsundervisningen i skolen, lader sig beskrive, analysere og fortolke ved hjælp af modellerne - i en enkelt og overskuelig form. Desuden forankrer modellerne religionsdidaktik og religionsundervisning i en almen didaktisk og dannelsesteoretisk begrundelsesstruktur, der både principielt og praktisk ligestiller disse almene videnskabelige discipliner med religionsundervisningens traditionelle basisfag, således at vi kan modvirke både ensidig nedsivning af basisfag og en fagligt uforpligtende almengørelse af fag, didaktik og undervisning. Vi må gøre dannelse og didaktik til den fælles horisont for vores religionsdidaktiske praksisser og samtaler uden at binde os til hverken den ene eller den anden form for normativitet.

\section{LitTERATUR}

Alberts, Wanda. 2007. Integrative religious education in Europe. Berlin: Walter de Gruyter

Andersen, Kirsten Margrethe \& Sigurdsson, Lakshmi. 2020. Religionsdidaktik $i$ praksis - dannelse til religiøs myndighed. København: Eksistensen

Andersen, Kirsten Margrethe \& Sigurdsson, Lakshmi. 2019a. «Praksisnær viden og refleksion over religion og dannelse». Tidsskrift for Professionsstudier, nr. 29, 54-61. https://tidsskrift.dk/tipro 
Andersen, Kirsten Margrethe \& Sigurdsson, Lakshmi. 2019b. "Qualifying didactic reflection in religious education through a model for religious competence». Nordidactica: Journal of Humanities and Social Science Education, 2019:4, 76-94. http://urn.kb.se/resolve?urn=urn:nbn:se:kau:diva-76262

Andreassen, Bengt-Ove. 2010. «Religionskritikk som dannelse». I Mary Brekke (red.), Dannelse i skole og laererutdanning. Oslo: Universitetsforlaget

Andreassen, Bengt-Ove. 2012. Religionsdidaktik. En innforing. Oslo: Universitetsforlaget

Arendt, Hannah. [1958] 2005. Menneskets vilkår. København: Gyldendal.

Bakker, Cok. 2016. «Professionalization and the Quest How to deal with Complexity». I Cok Bakker \& Nicolina Montesano Montessori (red.), Complexity in Education: From Horror to Passion. Rotterdam: Sense Publishers, p. $9-29$

Benner, Dietrich. 2001. Allgemeine Pädagogik. Weinheim: Juventa Verlag

Benner, Dietrich. 2005. Tekster til dannelsesfilosofi - mellem etik, peedagogik og politik. Aarhus: Klim

Benner, Dietrich \& Brüggen, Friedhelm. 2011. «Mündigkeit.» I Dietrich Benner \& Jürgen Oelkers (red.): Historisches Wörterbuch der Pädagogik. Studienausgabe (ss 687-699). Weinheim und Basel: Beltz

Bernstein, Basil. 2001. Paedagogik, diskurs og magt. Tid \& tanke. København: Akademisk

Briedlid, Halldis \& Nicolaisen, Tove. 2011. I begynnelsen var fortellingen. Oslo: Universitetsforlaget

Dobbelaere, Karel. 2002. Secularization. An Analysis at Three Levels. Brüssels: P.I.E.Peter Lang

Furseth, Inger \& Repstad, Pål. 2007. Religionssociologi. En introduktion. København. Hans Reitzels Forlag

Gruschka, Andreas. 2009. Erkenntnis in und durch Unterricht. Empirische Studien zur Bedeutung der Erkenntnis- und Wissenschaftstheorie für die Didaktik. Wetzlar: Büchse der Pandora

Gruschka, Andreas. 2016. At loere at forstå. Et forsvar for god undervisning. Aarhus: Klim

Habermas, Jürgen. 2009. Between Naturalism and Religion. Cambridge: Polity Press. Hovdenak, Sylvi Stenersen, \& Leganger-Krogstad, Heid. 2018. «Religion som fag - sett fra elevperspektiv «RLE er egentlig et av de viktigste fagene».- Prismet, 2018(1), 27-50. doi: https://doi.org/10.5617/pri.6152

Illum Hansen, Thomas \& Skovmand, Keld. 2011. Falles mål og midler. Laremidler og laereplaner i teori og praksis. Mål og midler. Århus: Klim

Illum Hansen, Thomas \& Skovmand, Keld 2008: «Den tabte opal», Religionspadagogisk forum, vol. 2008, nr. 1, 54-70 
Jaspers, Karl. [1919] 1990. Psychologie der Weltanschauungen. Berlin: Springer Jaspers, Karl. [1931] 2002. Die Geistige Situation der Zeit. Berlin: Springer

Juul, Henrik. 2020. «Kort overblik over grundskolens religionsfag». Tillæg til Henrik Juul \& Karna Kjeldsen. 2019: Religionsundervisning - en fagmetodik. København: Hans Reitzels Forlag. https://religionsundervisning-fagmetodik. digi.hansreitzel.dk/fileadmin/indhold/Artikel___Kort_overblik_over_grundskolens_religionsfag.pdf

Kant, Immanuel. [1784] 1993. «Besvarelse af spørgsmålet: Hvad er oplysning?» I Oplysning, historie, fremskridt. Historiefilosofiske skrifter. Udgivet af Morten Haugaard Jeppesen (ss 71-80). Slagmarks Skyttegravsserie. Århus: Slagmark

Klafki, Wolfgang. [1963] 1975. Studien zur Bildungstheorie und Didaktik. Durch ein kritisches Vorwort ergänzte Auflage 1975. Beltz Studienbuch. Weinheim und Basel: Beltz

Klafki, Wolfgang. 1985. Neue Studien zur Bildungstheorie und Didaktik. Beiträge zur kritisch-konstruktiven Didaktik. Weinheim: Beltz

Klafki, Wolfgang. [1996] 2011. Dannelsesteori og didaktik - nye studier. 3. udgave. Pædagogik til tiden. Århus: Klim

Kristensen, Jens Erik. 2008. «Modenhed, myndighed og dannelse - med særligt henblik på det religiøse». Kritisk Forum for Praktisk Teologi, 114, 5-28. Frederiksberg: Anis

Mortensen, Karen Marie. 2008. Karl Jaspers liv, samtaler og teenkning. Aalborg: Aalborg Universitetsforlag

Nielsen, Frede V. 2004. «Fagdidaktikkens kernefaglighed». I Karsten Schnack (red.), Didaktik på kryds og tvars (ss 25-45). København: Danmarks Pædagogiske Universitet

Nielsen, Frede V. 2012. «Fagdidaktik som integrativt relationsfelt». I Ellen Krogh \& Frede V. Nielsen (red.), Sammenlignende fagdidaktik 2. Cursiv nr. 92012 (ss 11-32). København: Institut for Uddannelse og Pædagogik. DPU. Aarhus Universitet

Nielsen, Frede V. [1994] 1998: Almen musikdidaktik. 2. udgave. København: Akademisk

Oettingen, Alexander von. 2007. «Medborgerskab-skolens nye dannelsesopgave?» I Ove Korsgaard, Lakshmi Sigurdsson \& Keld Skovmand (red.), Medborgerskab - et nyt dannelsesideal? (ss 47-67). Frederiksberg: Religionspædagogisk Forlag

Oettingen, Alexander von. 2010. Almen Padagogik. Paedagogikkens grundlaggende spørgsmål. København: Gyldendal

Oettingen, Alexander von. 2017. «De, der lever sammen, må også gå i skole sammen. Dannelse, paradokser og idealer». I Leif Moos (red.), Dannelse. Kontekster, visioner, temaer og processer (ss 193-213). København: Hans Reitzels Forlag 
Skeie, Geir. 2017. «Kan og bør religionsfaget bidra til personlig utvikling?» I Maria Von der Lippe, \& Sisse Undheim (red.). Religion i skolen. Didaktiske perspektiver på religions- og livssynsfaget (ss 117-129). Oslo: Universitetsforlaget

Sigurdsson, Lakshmi. 2019. «Religionsundervisningens smukke risiko». Religionslaereren nr. 4 (11-13)

Sigurdsson, Lakshmi. 2007. «Medborgerskab mellem religion, kultur og politik». I Ove Korsgaard, Lakshmi Sigurdsson \& Keld Skovmand (red.), Medborgerskabet nyt dannelsesideal? (ss 123-160). Frederiksberg: Religionspædagogisk Forlag.

Skovmand, Keld. 2007. «Religion som fællesmenneskelig praksisform», Religion og peedagogik, vol. 2007, nr. 1, s. 24-36

Skovmand, Keld. 2017. Ibund og grund-laererprofessionens didaktik? Ph.d.-afhandling. København: DPU, Aarhus Universitet

Uljens, Michael. 2008. «Dannelse og kritikkens mulighed». I Lars Emmerik Knudsen \& Mathias Anderson (red.), Skab dig! Pcedagogisk filosofi (ss 50-77). København: Unge Pædagoger

Undervisningsministeriet. 2019. Kristendomskundskab. Faghaefe 2019. København: Undervisningsministeriet. Tilgængelig på: https://emu.dk/sites/default/ files/2020-09/Gsk_fagh\%C3\%A6fte_Kristendomskundskab.pdf 
NYHET

JOSEF

\section{FORTALT AV TOR AGE BRINGSVÆRD}

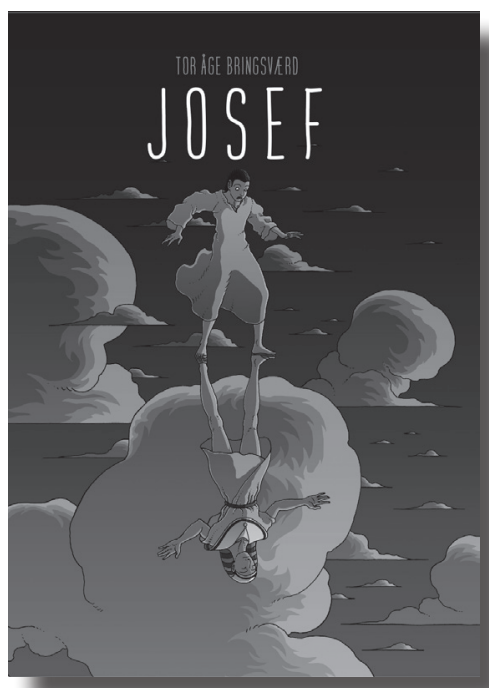

Historien om Josef har fascinert folk i flere tusen år. I denne boka har Tor Åge Bringsværd latt seg inspirere av blant annet jødisk legendetradisjon, Koranen og Bibelen. På sin helt særegne måte forteller Bringsværd den dramatiske historien om søskensjalusi, drømmer og tilgivelse. Boka har flotte Illustrasjoner av Thomas Falla Eriksen og små faktabokser som peker på de forskjellige tradisjonene.

Boka om Josef vil være et godt utgangspunkt for religionsdialog iskolen.

Tor Åge Bringsværd er en norsk forfatter kjent for romaner, barnebøker og fabelprosa. Han har mottatt en lang rekke priser for sitt arbeid. Fra debuten i 1967 har Bringsværd vært forfatter på heltid og bemerkelsesverdig produktiv.

\section{8 sider}

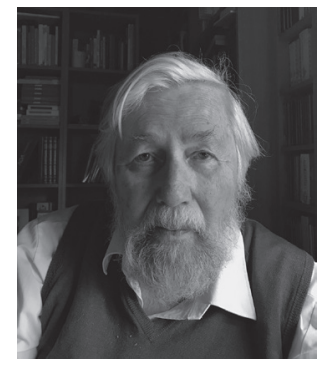

Utgivelsesår 2020

ISBN 978-82-8249-436-6

299,-

Boka kan kjøpes i nettbutikken på iko.no

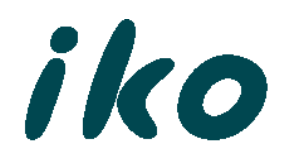

FORLAGET 


\title{
«A ta andres perspektiv»
}

\author{
Nytt kjerneelement og nye kompetansemål i fagene KRLE og \\ Religion og etikk
}

\begin{abstract}
Av Jon Magne Vestø1
Sammendrag: Denne artikkelen drefter aspekter ved perspektivtaking som kjerneelement og kompetansemål $i$ de nye laereplanene $i$ KRLE og Religion og etikk. Perspektivtaking sees $i$ lys av loreplaner og religionsvitenskapelige og religionsdidaktiske synspunkter, med sarlig vekt på forholdet mellom utenfra- og innenfra-perspektiv. Artikkelen trekker også inn empirisk materiale fra en studie av laerebokperspektiv og elevperspektiv. I lys av det empiriske materialet reflekterer artikkelen over mulige innganger til arbeid med perspektivtaking $i$ undervisningen, med scerlig vekt på bidrag fra innenfra-kilder.
\end{abstract}

Nøkkelord: Utenfra-perspektiv, innenfra-perspektiv, kjerneelement, læreplanmål.

Jon Magne Vestøl (f. 1954), Professor i religions- og etikkdidaktikk, Universitetet i Oslo. Pb.1099, Blindern.0317 Oslo.Epost:j.m.vestol@ils.uio.no

\section{INNLEDNING}

Med det nye læreplankonseptet «Fagfornyelsen» har fagene KRLE og Religion og etikk fått læreplaner med nye kompetansemål og såkalte «kjerneelementer». Ett av kjerneelementene er å «kunne ta andres perspektiv»:

"Kunne ta andres perspektiv - Faget skal gi mulighet for å utvikle egne synspunkter og holdninger i mote med andre gjennom innenfra- og utenfra-perspektiver og gjennom dialog og refleksjon over likheter og forskjeller. På den måten skal faget bidra til at elevene utvikler interesse og respekt for hverandre uavhengig av kulturell, sosial, religiøs eller livssynsmessig bakgrunn. Faget skal bidra til at elevene utvikler mangfoldskompetanse. Samiske perspektiver inngår. Temaer knyttet til kjønn og funksjonsevne inngår også.» (KD, 2020a, 2020b).

Ifølge kompetansemål for KRLE etter 10. trinn skal elevene kunne «utforske andres perspektiv og håndtere uenighet og meningsbrytning» (KD, 2020a). I faget Religion og etikk på vg3 skal eleven kunne «ta andres perspektiv og håndtere meningsbrytning om religion, livssyn og verdispørsmål» (KD, 2020b).

Det å forholde seg til ulike perspektiver er ikke en ny problemstilling i religionsvitenskap og religionsdidaktikk (Chryssides \& Greggs, 2019b; Eidhamar, 2019; McCutcheon, 1999; Mostowlansky \& Rota, 2016). Det nye kjerneelementet og de nye kompetansemålene framhever likevel dette på en langt mer eksplisitt måte enn i tidligere læreplaner. Leser man kjerneelementer og kompetansemål i

Prismet - IKO-Forlaget 2020

Tilgjengelig på https://journals.uio.no/index.php/prismet. Publisert under CC BY-NC 4.0. Fagfellevurdert 